\title{
Hypertension: an autoimmune disease?
}

\author{
Jan Willem Cohen Tervaert
}

Hypertension Research (2011) 34, 443-444; doi:10.1038/hr.2011.15; published online 24 February 2011

$I^{n}$ $\mathrm{n}$ the current issue of Hypertension Research, Stumpf et al. ${ }^{1}$ link $\mathrm{T}$ helper 1-mediated inflammation to essential hypertension. This study adds to the available evidence that the adaptive immune system contributes to hypertension.

The etiology of hypertension is still largely unknown. Although a pheochromocytoma, renal artery stenosis or Conn's disease can be detected in some patients with hypertension, in most such patients, no clear etiology can be found.

Some studies indicate that hypertension is a vascular disease, whereas others suggest that it is primarily a disease of sodium transport. Additionally, there is clear evidence that the central nervous system has a critical role in hypertension. In about half of hypertension patients, blood pressure remains high despite the use of antihypertensive therapy. Therefore, there is a clear need for therapeutic approaches based on new mechanistic insights.

Over the past three decades, studies have demonstrated that the immune system contributes to hypertension. First, increased blood pressure levels were found to be significant predictors of C-reactive protein levels (a nonspecific marker of inflammation). ${ }^{2}$ Second, T cells were shown to have a role in experimental models of hypertension. ${ }^{3-5}$ In addition, an increased incidence of hypertension has been found in immune-mediated diseases, such as rheumatoid arthritis and psoriasis. ${ }^{6}$ Furthermore, immunosuppressive therapy with mycophenolate mofetil, and possibly other immunosuppressive drugs, lowers blood pressure in these diseases. ${ }^{6,7}$ Finally, patients with acquired immune deficiency syndrome have a significantly lower

Dr JW Cohen Tervaert is at the Department of Internal Medicine, Division of Clinical and Experimental Immunology, Maastricht University Medical Center, PO box 5800, Maastricht 6202 MD, The Netherlands.

E-mail: jw.cohentervaert@immuno.unimaas.nl incidence of hypertension when the disease is untreated (that is, with low numbers of CD4 $\mathrm{T}$ cells), but blood pressure increases during highly active antiretroviral therapy (that is, with reconstitution of CD4 T cells). ${ }^{8}$ In 2007, a landmark study by Guzik et al. ${ }^{4}$ presented convincing evidence supporting a pathophysiological role for $\mathrm{T}$ cells in the development of hypertension. Mice that lacked T cells had a blunted response to angiotensin II infusion or deoxycorticosterone acetate (DOCA) salt challenge. Adaptive transfer of T cells completely restored blood pressure elevation.

The antigen that is recognized by $\mathrm{T}$ cells has not yet been extensively studied. Elevated levels of autoantibodies against oxidatively modified low-density lipoproteins can be detected in patients with hypertension, suggesting that oxidized low-density lipoprotein might be the antigen. ${ }^{9}$ Indeed, we recently demonstrated that immunoglobulin G antibodies to oxidized low-density lipoproteins were elevated in patients with cerebral small vessel disease as compared with patients with uncomplicated hypertension. ${ }^{10}$ Interestingly, protective immunoglobulin $\mathrm{M}$ antibodies were lower in patients with cerebral small vessel disease as compared with uncomplicated hypertension patients.

Activated (probably antigen specific) $\mathrm{T}$ cells infiltrate the fat adjacent to blood vessels and kidneys, resulting in a local release of cytokines, endothelial dysfunction and, subsequently, renal retention of sodium. These factors may ultimately cause persistent blood pressure elevations.

$\mathrm{T}$ cells express not only the T-cell receptor that recognizes antigens but also many costimulatory molecules. Neurohumoral receptors are also present on $\mathrm{T}$ cells. Importantly, angiotensin type 1 receptors are expressed on T cells. ${ }^{11}$ When stimulated by angiotensin II, skewing toward $\mathrm{T}$ helper 1 cells is observed. Stumpf et al. ${ }^{1}$ found that hypertensive patients had significantly higher
CXCL10/IP10 levels than controls and that plasma levels of CXCL10/IP10 correlated with systolic blood pressure. Previously, Antonelli et al. ${ }^{12}$ had also demonstrated significantly higher CXCL10/IP10 levels in patients with hypertension as compared with controls. CXCL10/IP10 is a chemokine that promotes the migration of activated $\mathrm{T}$ helper 1 cells into tissues. ${ }^{13}$

$\mathrm{T}$ helper 1 cells primarily express interleukin (IL) 2, interferon- $\gamma$ and tumor necrosis factor. By contrast, $\mathrm{T}$ helper 2 cells primarily express IL4, IL5, IL6 and IL13.

There is little evidence that $\mathrm{T}$ helper 2 cells also have a role in the pathogenesis of hypertension. However, Stumpf et al. ${ }^{1}$ not only confirmed previous findings that CXCL10-/ IP10 levels were elevated in hypertension (suggesting $\mathrm{T}$ helper 1 involvement) but also found elevated levels of $\mathrm{T}$ helper 2 cell cytokines, such as IL4 and IL13. ${ }^{1}$

$\mathrm{T}$ helper 2 cells are generally believed to be anti-inflammatory. However, experimental studies of atherosclerosis indicated that Th2 cells could accelerate the atherosclerotic process in certain conditions. ${ }^{14}$

In addition to $\mathrm{T}$ helper 1 and $\mathrm{T}$ helper 2 cells, $\mathrm{T}$ helper 17 cells were recently described. These cells have been implicated in the pathogenesis of many autoimmune diseases, such as rheumatoid arthritis and multiple sclerosis.

Remarkably, Madhur et al. ${ }^{15}$ recently demonstrated that patients with diabetes mellitus complicated by hypertension had significantly higher levels of IL17 (a marker of $\mathrm{T}$ helper 17 cells) than did diabetic patients who were normotensive. These findings suggest that, like T helper 1 and 2 cells, T helper 17 cells may be involved in the pathogenesis of hypertension. The fact that all these T-cell subsets might be activated indicates abnormal regulation of the immune system. Importantly, in the past decade, it became clear that several types of $\mathrm{T}$ cells are known to function as so-called regulatory $\mathrm{T}$ cells. In 
autoimmune diseases such as multiple sclerosis and rheumatoid arthritis, these regulatory $\mathrm{T}$ cells either are decreased in number or do not function correctly. Recently, Viel et al. ${ }^{16}$ demonstrated in an experimental rat model of genetic salt-sensitive hypertension that dysfunctional regulatory $\mathrm{T}$ cells were related to hypertension. ${ }^{16}$ These regulatory $\mathrm{T}$ cells should be further studied in patients with hypertension. Interestingly, vitamin $\mathrm{D}$ has recently received attention as a factor that may influence the function of regulatory $\mathrm{T}$ cells. ${ }^{17}$ Vitamin D deficiency is associated with hypertension, ${ }^{18}$ and a meta-analysis found that vitamin $\mathrm{D}$ supplementation resulted in a (small) reduction of systolic blood pressure. ${ }^{19}$

In conclusion, various T-cell subsets may have a role in hypertension. Clearly, more studies on the relationship between adaptive immune system and hypertension are needed to confirm the hypothesis that essential hypertension is an autoimmune disease.

1 Stumpf C, Auer C, Yilmaz A, Lewczuk P, Klinghammer L, Schneider M, Daniel WG, Schmieder RE, Garlichs CD. Serum levels of the Th1 chemoattractant interferon-gamma-inducible protein (IP) 10 are elevated in patients with essential hypertension. Hypertens Res 2011; 34: 484-488.
2 Blake GJ, Rifai N, Buring JE, Ridker PM. Blood pressure, C-reactive protein, and risk of future cardiovascular events. Circulation 2003; 108: 2993-2999.

3 Svendsen UG. Evidence for an initial, thymus independent and a chronic, thymus dependent phase of DOCA and salt hypertension in mice. Acta Pathol Microbiol Scand A 1976; 84: 523-528.

4 Guzik TJ, Hoch NE, Brown KA, McCann LA, Rahman A, Dikalov S, Goronzy J, Weyand C, Harrison DG. Role of the $T$ cell in the genesis of angiotensin II induced hypertension and vascular dysfunction. J Exp Med 2007; 204: 2449-2460.

5 Marvar PJ, Thabet R, Guzik TJ, Lob HE, McCann LA, Weyand C, Gordon FJ, Harrison DG. Central and peripheral mechanisms of T-lymphocyte activation and vascular inflammation produced by angiotensin IIinduced hypertension. Circ Res 2010; 107: 263-270.

6 Herrera J, Ferrebuz A, Macgregor EG, Rodriguez-Iturbe B. Mycophenolate mofetil treatment improves hypertension in patients with psoriasis and rheumatoid arthritis. J Am Soc Nephrol 2006; 17: S218-S225.

7 Ferro CJ, Edwards NC, Hutchison C, Cockwell P, Steeds RP, Savage CO, Townend JN, Harper L. Does immunosuppressant medication lower blood pressure and arterial stiffness in patients with chronic kidney disease? An observational study. Hypertens Res 2011; 34 : 113-119.

8 Seaberg EC, Munoz A, Lu M, Detels R, Margolick JB, Riddler SA, Williams CM, Phair JP, Multicenter AIDS Cohort Study. Association between highly active antiretroviral therapy and hypertension in a large cohort of men followed from 1984 to 2003. AIDS 2005; 19 : 953-960.

9 Maggi E, Marchesi E, Ravetta V, Martignoni A, Finardi G, Bellomo G. Presence of autoantibodies against oxidatevely modified low-density lipoprotein in essential hypertension: a biochemical signature of an enhanced in vivo low-density lipoprotein oxidation. J Hypertens 1995; 13: 129-138.

10 Rouhl RP, Van Oostenbrugge RJ, Theunissen RO, Knottnerus IL, Staals J, Henskens LH, Kroon AA, de Leeuw PW, Lodder J, Tervaert JW, Damoiseaux JG.
Autoantibodies against oxidized low-density lipoprotein in cerebral small vessel disease. Stroke 2010; 41: 2687-2689.

11 Shao J, Nangaku M, Miyata T, Inagi R, Yamada K, Kurokawa K, Fujita T. Imbalance of T-cell subsets in angiotensin II-infused hypertensive rats with kidney injury. Hypertension 2003; 42: 31-38.

12 Antonelli A, Fallahi P, Rotondi M, Ferrari SM, Romagnani $P$, Ghiadoni $L$, Serio M, Taddei S, Ferrannini E. High serum levels of CXC chemokine ligand 10 in untreated essential hypertension. J Hum Hypertens 2008; 22: 579-581.

13 Loetscher M, Gerber B, Loetscher P, Jones SA, Piali L, Clark-Lewis I, Baggiolini M, Moser B. Chemokine receptor specific for IP10 and mig: structure, function, and expression in activated T-lymphocytes. J Exp Med 1996; 184: 963-969.

14 Mallat Z, Taleb S, Ait-Oufella H, Tedgui A. The role of adaptive $T$ cell immunity in atherosclerosis. $J$ Lip Res 2009; 50: S364-S369.

15 Madhur MS, Lob HE, McCann LA, Iwakura Y, Blinder Y, Guzik TJ, Harrison DG. Interleukin 17 promotes angiotensin II-induced hypertension and vascular dysfunction. Hypertension 2010; 55: 500-507.

16 Viel EC, Lemarié CA, Benkirane K, Paradis P, Schiffrin EL. Immune regulation and vascular inflammation in genetic hypertension. Am J Physiol Heart Circ Physiol 2010; 298: H938-H944.

17 Smolders J, Thewissen M, Peelen E, Menheere P, Tervaert JW, Damoiseaux J, Hupperts R. Vitamin D status is positively correlated with regulatory $T$ cell function in patients with multiple sclerosis. PLoS One 2009; 4: e6635.

18 Burgaz A, Byberg L, Rautiainen S, Orsini N, Håkansson $\mathrm{N}$, Arnlöv J, Sundström J, Lind L, Melhus H, Michaëlsson K, Wolk A. Confirmed hypertension and plasma 25(OH)D concentrations amongst elderly men. J Intern Med 2011; 269: 211-218.

19 Pittas AG, Chung M, Trikalinos T, Mitri J, Brendel M, Patel K, Lichtenstein AH, Lau J, Balk EM. Systematic review: vitamin D and cardiometabolic outcomes. Ann Intern Med 2010; 152: 307-314. 